\title{
RELACJE POLSKO-NIEMIECKIE A RACJA STANU. SPÓR PIS - PO O MODEL POLITYKI ZAGRANICZNEJ WOBEC REPUBLIKI FEDERALNEJ NIEMIEC (2001-2015)
}

\begin{abstract}
Analiza dyskursu politycznego po 2001 roku skłania do wniosku, że jednym z obszarów spornych między PO a PiS był model relacji polsko-niemieckich. O ile obie partie zgadzały się co do tego, że dobre relacje z państwami ościennymi, w tym z Niemcami, stanowią treść polskiej racji stanu, o tyle spór koncentrował się na kwestiach szczegółowych dotyczących dróg realizacji celów wynikających z raison d'état. Zasadnicze różnice i spory między obiema partiami wynikały z propagowania różnych modeli polityki zagranicznej. Stanowisko PO bliskie było liberalnemu podejściu do relacji międzynarodowych oraz ponowoczesnemu modelowi państwa. Zwolennicy państwa ponowoczesnego nie przywiązywali wagi do suwerenności jako szczególnego atrybutu państwa, a interes państwowy traktowali jako coraz mniej determinujący czynnik w polityce zagranicznej. PiS natomiast hołdowało paradygmatowi realistycznemu, uważając, że stosunki międzynarodowe były nieustanną areną walki między partykularnymi interesami poszczególnych państw, gdzie rządzą narodowe egoizmy. Uznawano, że tylko podejście realistyczne gwarantuje dobre relacje bilateralne z Niemcami.
\end{abstract}

Słowa kluczowe: racja stanu, myśl polityczna, partie polityczne, relacje polsko-niemieckie.

\section{UWAGI WSTĘPNE}

Stosunki dwustronne z Niemcami od 1989 roku należały do priorytetów polskiej polityki zagranicznej. Współcześnie RFN jest dla Polski nie tylko sąsiadem, ale także sojusznikiem w NATO, najważniejszym partnerem gospodarczym, współczłonkiem Unii Europejskiej. Ponadto Niemcy pozostają najsilniejszym gospodarczo i politycznie państwem w regionie i UE.

Począwszy od 1989 roku kształtowanie się stosunków polsko-niemieckich było procesem niezwykle dynamicznym i wieloetapowym ${ }^{2}$. Po wejściu Polski do Unii Europejskiej w 2004 roku nastąpiła europeizacja relacji polsko-niemieckich. Doszło do zmiany warunków kształtujących polską rację stanu, a w jej rezultacie przedmiotowej transformacji raison d'état. W warunkach kształtowania się struktur ponadpaństwowych i ponadnarodo-

\footnotetext{
${ }^{1}$ Dr Joanna Sanecka-Tyczyńska, adiunkt, Zakład Teorii Polityki i Metodologii Politologii, Wydział Politologii Uniwersytetu Marii Curie-Skłodowskiej, Plac Litewski 3, 20-080 Lublin; e-mail: j.sanecka-tyczynska@ poczta.umcs.lublin.pl.

2 O periodyzacji i etapach kształtowania się relacji polsko-niemieckich w: M. Stolarczyk, Zbieżność i różnice interesów w stosunkach polsko-niemieckich w latach 1989-2009, Prace Naukowe Uniwersytetu Śląskiego w Katowicach, nr 2819, Katowice 2010, s. 12-13.
} 
wych naturalnym zjawiskiem wydawał się proces zmniejszania się roli interesów państwowych kosztem wartości wspólnotowych. Rosnąca współzależność państw spowodowała konieczność odchodzenia od wąskiego ujmowania racji stanu, tylko i wyłącznie w kategorii interesów państwa. Istota współczesnych stosunków międzynarodowych polega na łączeniu interesów indywidualnych z międzypaństwowymi. Udział w sojuszach politycznych sprzyjał umiędzynarodowieniu państwowych racji stanu. W tym kontekście nader ważne wydaje się budowanie wspólnoty interesów z państwami sąsiednimi w zakresie wartości, bezpieczeństwa czy współpracy gospodarczej3 ${ }^{3}$.

Od 2008 roku globalne warunki geopolityczne uległy dalszej, wyraźnej zmianie. Doszło do reorientacji amerykańskiej polityki zagranicznej (utrata zainteresowania Europą, przeniesienie uwagi na Daleki Wschód, rezygnacja z projektu tarczy antyrakietowej oraz „reset” w stosunkach z Rosją), podjęcia prób restauracji strefy wpływów przez Rosję (wojna w Gruzji i na Ukrainie, wykorzystywanie surowców energetycznych jako narzędzia politycznego szantażu oraz propozycja nowej struktury bezpieczeństwa w Europie), przekształceń instytucjonalnych wewnątrz Unii Europejskiej, tworzących pozory jednolitej polityki zagranicznej (traktat lizboński), ewolucji niemieckiej polityki zagranicznej i prób relatywizacji historii. Wszystkie te zmiany były potencjalnie niekorzystne, biorąc pod uwagę polską rację stanu ${ }^{4}$.

Racja stanu Polski wymagała kształtowania jak najlepszych relacji i projektowania dalekosiężnych wizji współpracy z państwami ościennymi. Choć racja stanu była pojęciem pojemnym znaczeniowo, a przez to spornym, to jednocześnie często używanym w polskim dyskursie politycznym i medialnym. Racja stanu w dużym uproszczeniu była rozumiana jako system interesów państwa wewnętrznych i międzynarodowych realizowanych w sposób bezkompromisowy ${ }^{5}$.

Relacje bilateralne z państwami ościennymi są częścią polityki zagranicznej. Pomiędzy polityką zagraniczną państwa a racją stanu zachodzą obustronne zależności. Z jednej strony, w procesach polityki zagranicznej następuje odczytywanie, definiowanie i weryfikowanie treści racji stanu oraz określanie głównych motywów działania państwa w środowisku międzynarodowym. Z drugiej zaś strony, racja stanu warunkuje i wyznacza dalekosiężne cele strategiczne w dziedzinie politycznej, gospodarczej, wojskowej, kulturalnej etc. Raison d'état wymaga dobrego rozpoznania środowiska międzynarodowego, przewidywania jego zmian. Polska należy do tych państw europejskich, które szczególnie muszą się liczyć w działaniach politycznych z aktualną polityką europejską i światową. Proces korelacji racji

\footnotetext{
${ }^{3}$ S. Bieleń, Polityka zagraniczna a racja stanu [w:] Polityka zagraniczna państwa, red. J. Kukułka, R. Zięba, Warszawa 1992, s. 187-188.

${ }^{4}$ Ł. Warzecha, Czy możliwa jest realistyczna polityka zagraniczna nie na kolanach, czyli o fatszywej interpretacji realizmu [w:] Rzeczpospolita na arenie międzynarodowej. Idee i praktyczne dylematy polityki zagranicznej, red. J. Kloczkowski, T. Żukowski, Warszawa-Kraków 2010, s. 104.

5 Więcej o kategorii racji stanu w: Z.J. Pietraś, Racja stanu w polityce zagranicznej państwa [w:] Racja stanu. Historia. Teoria. Wspótczesność, red. E. Olszewski, Lublin 1989; A. Rzegocki, Idea raison d'état w przeszłości i w kontekście wspótczesnej integracji europejskiej, Warszawa 2003; K. Łastawski, Polska racja stanu po wstapieniu do UE, Warszawa 2006; P.G. Cerny, The competition state today: from raison d'État to raison du Monde, "Policy Studies" Vol. 31, 2010; H. Groszyk, Refleksje o niektórych aspektach idei racji stanu [w:] Studia z historii państwa i idei, red. A. Korobowicz, H. Olszewski, Lublin 1997; E. Sadowski, Racja stanu w polityce zagranicznej państwa [w:] Wstęp do teorii polityki zagranicznej państwa, red. R. Zięba, Torun 2004.
} 
stanu różnych państw jest szczególnie wyraźny w przypadku funkcjonowania sojuszy. Poszukiwaniu zbieżnych wartości i interesów towarzyszy wymóg zgodności w procesie realizacji wspólnej polityki obronnej i stanowiska wobec środowiska międzynarodowego ${ }^{6}$.

Choć rację stanu słusznie kojarzymy z polityką państwa i mówimy o jednej raison d'état danego państwa, to myśl polityczna poszczególnych partii politycznych zawiera definicje racji stanu, katalog priorytetów polityki, pomysły na ich realizację i stanowi pierwszy krok w formułowaniu państwowej racji stanu, która odzwierciedla się i realizuje poprzez decyzje elity rządzącej. Treść owej racji stanu (rozumianej jako kategoria myśli politycznej) jest różna w zależności od przynależności do nurtu ideologicznego. Spory o polską rację stanu są obecne od 1989 roku, a pojęcie racji stanu jest stosowane w dyskursie dotyczącym polityki zagranicznej oraz w codziennej praktyce stosunków międzynarodowych wymiennie z pojęciem ,interesu narodowego”.

Od 2005 roku polski dyskurs polityczny zdominowany został przez spory między dwiema partiami powstałymi w 2001 roku: Prawem i Sprawiedliwością oraz Platformą Obywatelską RP. Dwa ugrupowania odgrywające główną rolę na scenie politycznej od 2005 roku, wywodzące się $\mathrm{z}$ tego samego pnia ideologicznego, mające podobną genezę zabiegały o prawicowy elektorat. Pomimo zapewnień w okresie poprzedzającym kampanię wyborczą 2005 roku o planach koalicyjnych i ideowej bliskości, spór pomiędzy dwiema partiami dotyczył podstawowych zagadnień. O ile można było zauważyć konsensus w kwestii, co jest polską racją stanu, o tyle w sprawach szczegółowych pojawiały się spory jakimi metodami i narzędziami realizować cele, wynikające z raison d'état.

Analiza dyskursu politycznego po 2001 roku skłania do wniosku, że jednym z obszarów spornych między PO a PiS był model relacji polsko-niemieckich. O ile obie partie zgadzały się, co do tego, że dobre relacje z państwami ościennymi, w tym z Niemcami stanowią treść polskiej racji stanu, o tyle spór koncentrował się na kilku problemach: 1) ocenie stosunków polsko-niemieckich, 2) modelu relacji bilateralnych z Niemcami oraz 3) pożądanej roli Niemiec w UE (szczególnie w czasie kryzysu „strefy euro”).

\section{PRAWO I SPRAWIEDLIWOŚĆ WOBEC STOSUNKÓW POLSKO-NIEMIECKICH}

Poglądy polityków PiS na model stosunków polsko-niemieckich wynikały z dwóch ważnych przesłanek: negatywnej oceny polityki zagranicznej wobec Niemiec prowadzonej przez gabinety rządowe po 1989 r. oraz kierowania się postawą charakterystyczną dla realizmu politycznego $\mathrm{w}$ odniesieniu do relacji międzynarodowych.

Oceniano, że polska polityka wobec Niemiec w ostatnich dwóch dekadach nie służyła partnerstwu, ale poprzez wiele zaniechań generowała coraz to nowe napięcia. Najbardziej krytycznie oceniano działania rządu Donalda Tuska, który według polityków PiS w stosunku do Niemiec przyjął postawę klientystyczną, wasalną, a nawet serwilistyczną. Wymieniano uchybienia, wpływające na niską efektywność polityki zagranicznej względem Niemiec: (1) brak reakcji na korektę niemieckiej polityki historycznej, która kwestionowała prawdę historyczną i moralny sens II wojny światowej, (2) klęska w sprawie rurociągu północnego i groźby zablokowania portu w Świnoujściu, (3) żadnych pozytywnych rozstrzy-

\footnotetext{
${ }^{6}$ S. Bieleń, op. cit., s. 186-187; A. Wolff-Powęska, Polska racja stanu w procesie normalizacji stosunków z Niemcami w warunkach wolności i demokracji [w:] Polska - Niemcy 1945-2007. Od konfrontacji do wspótpracy i partnerstwa w Europie, red. W.M. Góralski, Warszawa 2007, s. 205.
} 
gnięć w kwestii praw Polaków w Niemczech i brak reakcji na coraz częstsze przypadki odbierania dzieci polskim rodzinom przez niemieckie urzędy ds. ochrony dzieci i młodzieży (Jugendamt), (4) nieskuteczne zabiegi o niemieckie poparcie dla umieszczenia Europejskiego Instytutu Technologicznego we Wrocławiu. W ocenie polityków PiS pozytywnym przejawem polityki wobec Niemiec po 1989 roku była decyzja o udziale w wojnie w Iraku oraz wsparcie dla ,pomarańczowej rewolucji” na Ukrainie, które oznaczały w praktyce zerwanie z klientyzmem i uległością w stosunkach międzynarodowych oraz były oznaką polskiej podmiotowości? .

Analiza świadectw i śladów myśli politycznej PiS prowadzi do wniosku, że w koncepcji polityki zagranicznej wobec RFN kreowanej przez PiS dominującą postawą był realizm polityczny. Kierowanie się realizmem politycznym uznawano za gwarancję sukcesu w relacjach z sąsiadami. To właśnie realiści, szczególnie zachodni często odwoływali się do kategorii raison d'état. W kategoriach racji stanu rozpatrywano relacje Polski z państwami sąsiednimi, szczególnie zaś z Niemcami i Federacją Rosyjskąa ${ }^{8}$.

Zgodnie z paradygmatem realistycznym każde państwo ukierunkowane jest na realizację i obronę interesów państwowych i narodowych, dlatego też wątpiono we wspólnotę polskich i niemieckich interesów, mówiąc jedynie o punktach stycznych polityki obu państw.

Polaryzację polityczną uważano za naturalne zjawisko w środowisku międzynarodowym, gdzie rywalizują różne wizje i wartości. O egzystencji państwa decyduje zatem zdolność do realizacji własnej racji stanu, a błędem było uleganie złudzeniom i aktualnie panującym trendom (traktowanym jako czynniki irracjonalne) ${ }^{9}$.

Prawo i Sprawiedliwość oraz eksperci skupieni wokół tej partii byli przekonani o dysonansie polskich i niemieckich interesów w Europie. Rozbieżności skupiały się wokół kilku kwestii.

Po pierwsze - politycy PiS wskazywali na liczne dysproporcje we wzajemnych relacjach. Dominowało przekonanie o nadmiernej (w stosunku do rzeczywistego potencjału) roli Niemiec w Europie, w jej instytucjonalnym i realnym wymiarze. Z owego zapatrywania wyłonił się polityczny zamysł instytucjonalnego ograniczenia roli zachodniego sąsiada Polski w Unii Europejskiej, poprzez forsowanie „systemu pierwiastkowego” jako podstawy

${ }^{7}$ Program Prawa i Sprawiedliwości 2014, Warszawa 2014, s. 41-42; Raport o stanie Rzeczypospolitej, Warszawa 2011, s. 110; J. Kaczyński, Polska racja stanu [w:] Racja stanu - Janowi Olszewskiemu, red. B. Jusiak, Poznań 2011, s. 32; tegoż, Nie odtwarzajmy Cesarstwa Niemieckiego, „Rzeczpospolita” z 8.07.2011 r., s. A16.

8 Wypowiedź Jarosława Kaczyńskiego po informacji rządu na temat polskiej polityki zagranicznej w 2003 roku, http://orka2.sejm.gov.pl/Debata4.nsf/9a905bcb5531f478c125745f0037938e/ (dostęp: 3.07.2015 r.); Wypowiedź Kazimierza Michała Ujazdowskiego po informacji ministra spraw zagranicznych o zadaniach polskiej polityki zagranicznej w 2005 roku, http://orka2.sejm.gov.pl/Debata4.nsf/9a905bcb5531f478c125745f0037938e/ (dostęp: 3.07.2015 r.).

9 T. Łoś-Nowak, Paradygmat realistyczny - projekcje porzadku międzynarodowego $w$ XXI wieku [w:] Porzadek międzynarodowy u progu XXI wieku, red. R. Kuźniar, Warszawa 2005, s. 21-34. J. Czaputowicz, Teorie stosunków międzynarodowych. Krytyka i systematyzacja, Warszawa 2008 , s. 58 i n. Zob. W. Paruch, M. Rydel, Zatożenia strategiczne w koncepcji polityki zagranicznej RP analiza myśli politycznej Prawa i Sprawiedliwości [w:] Polityka zagraniczna III RP. 20 lat po przetomie, t. 1: Koncepcje, bezpieczénstwo, kwestie prawne i polonijne, red. A. Jarosz, K. Olszewski, Torun 2011, s. 199. 
głosowań w Radzie Europejskiej ${ }^{10}$. Politycy PiS przyznawali, że Niemcy wsparły polskie starania o członkostwo w NATO i Unii Europejskiej, ale ich zaangażowanie wynikało z chłodnych politycznych kalkulacji. Akcesja Polski do Unii leżała w gospodarczym interesie Niemiec. Zachodni sąsiad Polski, będącej państwem tranzytowym do Rosji obawiał się słabej i nieprzewidywalnej gospodarki tuż za swoją wschodnią granicą ${ }^{11}$.

Wielokrotnie podkreślano, że znaczny dysonans i różnice gospodarcze między obu państwami nie uzasadniały dużej dysproporcji politycznej, szczególnie lekceważenia polskich interesów narodowych. Jako przykład nierówności podawano brak uznania dla istnienia mniejszości polskiej w Niemczech, choć jednocześnie Polska tworzyła komfortowe warunki do rozwoju niemieckiej mniejszości. Dysproporcje tworzyły ,iluzoryczną wspólnotę interesów z Niemcami”, która pozornie miała torować drogę ku centrum decyzyjnemu Unii. W ocenie PiS założenie przyjęte przez polityków PO, że przyjęcie waluty euro zapewni w przyszłości Polsce pozycję jednego z głównych decydentów w Unii było błędne. Plany PO dotyczące przyjęcia wspólnej waluty określono jako „,zakamuflowany, ale nadal proniemiecki, kliencki kurs na całkowitą symbiozę z gospodarką niemiecką, bez żadnej gwarancji na sukces gospodarczy i polityczny" ${ }^{2}$.

W ocenie Krzysztofa Szczerskiego, posła PiS, Niemcy musiałyby spełnić cztery warunki, aby relacje Polski z zachodnim sąsiadem można było uznać za partnerskie: (1) przestrzeganie praw Polaków mieszkających na stałe w RFN, którzy nie mają statusu mniejszości narodowej ${ }^{13}$; (2) zmiana paradygmatów niemieckiej polityki wschodniej i uwzględnienie udziału Polski, Stanów Zjednoczonych Ameryki Północnej i Paktu Północnoatlantyckiego w budowaniu trwałego pokoju w regionie. Według polityka PiS, format normandzki, czyli negocjacje w gronie Niemcy, Francja, Rosja i Ukraina, wyczerpał swoje możliwości i okazał się nieskuteczny, (3) zniesienie niemieckiej blokady politycznej na budowę baz NATO w Polsce oraz (4) uwzględnienie przez Niemcy polskich interesów energetycznych i kreowanie takiej polityki klimatycznej i energetycznej Unii Europejskiej, która umożliwi-

${ }^{10}$ Dylematy $i$ perspektywy stosunków polsko-niemieckich, http://www.stosunkimiedzynarodowe. info/artykul,587,Dylematyiperspektywy_stosunkow_polskoniemieckich (dostęp: 2.07.2015 r.).

11 A. Fotyga, Sojusze zawieramy wedle interesów, rozm. J. Olechowski, W. Lorenz, „Rzeczpospolita” z 18.05.2007, s. A5; Wypowiedź Arkadiusza Mularczyka po informacji ministra spraw zagranicznych o zadaniach polskiej polityki zagranicznej w 2015 r., http://www.sejm.gov.pl/Sejm7.nsf/wypowiedz.xsp?posiedzenie $=91 \&$ dzien $=2 \& w y p=42 \&$ view $=S$ (dostęp: 3.07 .2015 r.).

12 Wątpiono w skuteczność współpracy z Niemcami w ramach Trójkąta Weimarskiego. Wydaje się, że nienajlepsze stosunki z Niemcami i odmienne stanowisko w kwestii wojny w Iraku (Niemcy i Francja stanęły po przeciwnej niż Polska, ,,antyamerykańskiej” stronie w konflikcie w Zatoce Perskiej) wpłynęły na negatywną ocenę tego porozumienia. Wypowiedź Witolda Waszczykowskiego po informacji ministra spraw zagranicznych o założeniach polskiej polityki zagranicznej w 2013 r., http://www.sejm.gov.pl/Sejm7.nsf/wypowiedz.xsp?posiedzenie=36\&dzien=1\&wyp= 4\&type=A\&symbol, (dostęp: 23.06.2015 r.); Waszczykowski: Chcemy dokonać korekty w relacjach z Niemcami, http://natemat.pl/145845, chcemy-dokonac-korekty-w-relacjach-z-niemcamiwaszczykowski (dostęp: 2.07.2015 r.); Trójkąt Weimarski: propaganda zamiast narzędzia, http://ryszardczarnecki.blog.onet.pl/tag/francja/ (dostęp: 4.07.2015 r.).

${ }^{13}$ Więcej w: J. Santorski, Problem Polonii niemieckiej w zjednoczonych Niemczech - aspekty historyczne, polityczne i prawnomiędzynarodowe [w:] Przełom i wyzwanie. XX lat polsko-niemieckiego Traktatu o dobrym sąsiedztwie i przyjaznej wspótpracy 1991-2011, red. W.M. Góralski, Warszawa 2011, s. 629 i nast.; A. Graś, Pozycja prawna Polaków w Niemczech [w:] Być Polakiem w Niemczech, red. A. Wolff-Powęska, E. Schulz, Poznań 2000. 
łaby utrzymanie wydobycia polskiego węgla. „Strategiczne stosunki są możliwe tylko między równorzędnymi partnerami” - podkreślił Szczerski ${ }^{14}$.

Po drugie - głównymi osiami sporu z niemieckimi elitami rządzącymi była wizja przyszłej Unii Europejskiej (federalistyczne cele Niemiec zagrażały modelowi „Europy ojczyzn”) oraz jej charakter społeczno-gospodarczy (odchodzenie od idei solidarności). Politycy PiS byli przekonani, że w interesie Niemiec leżało wzmocnienie UE, traktowanej jako instrument budowania coraz silniejszej pozycji międzynarodowej, stąd priorytetowe podejście do prac nad unijną reformą instytucjonalną ${ }^{15}$.

Po trzecie - PiS negowało niemiecką strategię rozwoju relacji z Federacją Rosyjską. W zakresie polityki zagranicznej UE wizja niemiecko-rosyjskiego partnerstwa strategicznego, określającego losy Europy Środkowej była uważana przez polityków PiS za sytuację godzącą w polską rację stanu i realizację ,kondominium niemiecko-rosyjskiego” w regionie. Przejawem ścisłej współpracy niemiecko-rosyjskiej była realizacja Gazociągu Północnego. Podkreślano, że państwo działające wbrew polskiej racji stanu nie może być nazywane partnerem. Dla PiS, które priorytetowo traktowało kwestie bezpieczeństwa Polski, plany, a potem budowa gazociągu omijającego terytorium Polski były uważane za cios w raison d'état Rzeczypospolitej Polskiej.

Rosyjsko-niemiecki projekt Gazociągu Północnego był uważany przez polityków PiS za „skrajnie niebezpieczny” dla Polski z dwóch powodów: (1) w sensie politycznym, porozumienie rosyjsko-niemieckie było przykładem złamania wszelkich norm i obyczajów europejskich (przeważył egoizm narodowy nad europejską i sąsiedzką solidarnością). Brak konsultacji z państwami sąsiednimi, bez próby skoordynowania tej inwestycji z innymi projektami energetycznymi w regionie źle rokowało na przyszłość. (2) w sensie ekonomicznym i bezpieczeństwa energetycznego istniałaby uzasadniona groźba presji ze strony rynku niemieckiego i rosyjskiego na polski rynek gazu, z czasem pojawiłaby się tendencja do reeksportu gazu do Polski, z nałożeniem niekorzystnych dla Polski marż, zniweczenie planów zróżnicowania źródeł dostaw gazu do Polski oraz niebezpieczeństwo rosyjskiej presji energetycznej na Białoruś i Ukrainę $e^{16}$.

Po czwarte - istniał spór z Niemcami o model bezpieczeństwa Europy Wschodniej. Politycy PiS, dla których Stany Zjednoczone Ameryki Północnej były głównym gwarantem

${ }^{14}$ K. Szczerski, Cztery warunki Dudy dla Niemiec, rozm. J. Bielecki, „Rzeczpospolita” z 15.06. 2015 r., s. A6; tegoż, Będziemy prowadzić politykę z podniesiona głową, rozm. M. Michalska, „Gazeta Polska” z 24.08.2014 r., s. 12-13.

${ }_{15}$ Dylematy $i$ perspektywy stosunków polsko-niemieckich, http://www.stosunkimiedzynarodowe. info/artykul,587,Dylematyiperspektywy_stosunkow_polskoniemieckich (dostęp: 2.07.2015 r.).

16 P. Naimski, Rosja chce być energetycznym monopolista, rozm. I. Janke, „Rzeczpospolita” z 11.01.2008 r., s. A18-A19. W literaturze przedmiotu dominowało przekonanie, że Niemcy w polityce wobec Rosji popierały okcydentalizację Europy Wschodniej oraz Kaukazu i, co za tym idzie, propagowaną przez Polskę inicjatywę Partnerstwa Wschodniego tylko w takim zakresie, w jakim nie wchodziła ona w konflikt z Rosją. Polska obawiała się Rosji silnej, odrodzonej i geopolitycznie aktywnej, Niemcy zaś - Rosji słabej, chylącej się ku upadkowi, ponieważ uniemożliwiłoby to prowadzenie długotrwałej i stabilizującej polityki na Wschodzie i ograniczałoby gospodarczą ekspansję na Wschód. P. Musiałek, Trendy zewnętrznych uwarunkowań polityki zagranicznej Polski w latach 2007-2011. Ewolucja najbliższego środowiska międzynarodowego [w:] Główne kierunki polityki zagranicznej rzadu Donalda Tuska w latach 2007-2011, red. P. Musiałek, Kraków 2012, s. 36; S. Michałowski, Partnerstwo Wschodnie w polityce zagranicznej Niemiec, „Homo Politicus” Vol. 7-8, 2012-2013, s. 60; M. Stolarczyk, op. cit., s. 585. 
bezpieczeństwa Polski nie zgadzało się z koncepcją forsowaną przez Niemcy. W niemieckich planach nie było miejsca dla obecności Amerykanów na terenie Europy w wymiarze militarnym. O ile Polsce zależało na oddaleniu niebezpieczeństwa rosyjskiego, o tyle niemieckie propozycje w zakresie bezpieczeństwa UE wzmacniałyby geopolityczną rolę $\mathrm{Fe}-$ deracji Rosyjskiej ${ }^{17}$. W kręgach PiS dominowało myślenie w kategoriach tradycyjnej Realpolitik, w której główne miejsce zajmowały klasyczne (militarne) środki wzmacniania bezpieczeństwa (hard power). Natomiast elity rządzące w Niemczech przywiązywały wagę do stosowania środków o charakterze politycznym, ekonomicznym, kulturalnym (soft power $)^{18}$.

Po piąte - stosunek do historii, a w szczególności do II wojny światowej ${ }^{19}$. W ocenie polityków PiS wspólne celebrowanie rocznic nie przyniosło spodziewanych rezultatów. PiS, które traktowało politykę historyczną w kategoriach racji stanu, stawiało na twardą obronę polskich interesów, wyraźnego określenia kto jest ofiarą, a kto sprawcą II wojny światowej. Politycy PiS jawili się jako zwolennicy polityzacji historii, by za jej pomocą budować podmiotowość międzynarodową i realizować cele strategiczne. Wskazywano na pragmatyczny wymiar polityki historycznej, która wpływała i wpływa na kształt wzajemnych relacji między państwami ${ }^{20}$.

W myśli politycznej PiS dominowało przekonanie, wyartykułowane przez Krzysztofa Szczerskiego, że w relacjach, tak z Rosją, jak i Niemcami Polska powinna ,zachowywać pole dla własnego działania wobec tych dwóch państw”. W tym celu należałoby podjać dwa rodzaje aktywności. Pierwsza miałaby polegać na budowaniu własnej przestrzeni politycznej w regionie poprzez kształtowanie dobrych relacji z państwami położonymi od Morza Bałtyckiego po Morze Czarne, Bałkany i Kaukaz. Drugi rodzaj działań dotyczył prowadzenia aktywnej i podmiotowej polityki, polegającej na odważnym artykułowaniu interesów i celów polskiej polityki, by móc „reagować na każde wydarzenie, które następuje w Europie oraz w stosunkach między Europą i Stanami Zjednoczonymi"21.

\section{PLATFORMA OBYWATELSKA A RELACJE POLSKO-NIEMIECKIE}

Zasadniczo odmienny punkt widzenia na współczesne Niemcy prezentowali politycy PO. W ścisłych relacjach z RFN upatrywano szansy na przełamanie „klątwy położenia geopolitycznego Polski: między Niemcami a Rosją" i trwałe zakorzenienie Polski w strukturach zachodnich, gdzie Niemcy odgrywały decydującą rolę, obok Stanów Zjednoczonych Ameryki Północnej. Dla PO „płynięcie w głównym nurcie” polityki europejskiej (pod nieformalnymi auspicjami Niemiec) gwarantowałoby realizację polskich interesów państwowych $^{22}$

${ }^{17}$ Od lat jesteśmy $w$ sporze o bezpieczeństwo Europy Wschodniej z Niemcami, http://wiadomosci.onet.pl/kraj/waszczykowski-od-lat-jestesmy-w-sporze-o-bezpieczenstwo-europy-wschodniej-z-niemcami/9s2jhy (dostęp: 21.06.2015 r.).

18 M. Stolarczyk, op. cit., s. 511; Zob. J. Kiperska, USA w polityce Niemiec, „Przegląd Zachodni” nr 1, 2008, s. 87-113.

${ }^{19}$ Program Prawa i Sprawiedliwości 2014..., s. 156.

20 W. Paruch, M. Rydel, op. cit., s. 197; J. Kaczyński, Polska racja stanu..., s. 33-34.

${ }^{21}$ K. Szczerski, Będziemy prowadzić politykę..., s. 12-13.

${ }^{22}$ Polska a przyszłość Unii Europejskiej. Wystąpienie Radosława Sikorskiego, Ministra Spraw Zagranicznych w Berlinie 28 listopada 2011 r., www.msz.gov.pl/resource/c2a33d88-7b8d-4fa58680-a67a4b2b38af:JCR (dostęp: 10.07.2015 r.). 
W prezentowanych koncepcjach polityki zagranicznej było widoczne liberalne podejście do stosunków międzynarodowych. Ujęcie liberalne (idealistyczne) zakładało, że w środowisku międzynarodowym powinna wzrastać rola prawa międzynarodowego i organizacji międzynarodowych. Siła państwa nie była tak istotna jak twierdzili realiści, a politykę państwa należało analizować z perspektywy globalnej. Interes narodowy nie był jedyną i najważniejszą kategorią, którą państwo powinno się kierować w polityce wewnętrznej i międzynarodowej. Równie ważne były interesy społeczne. W motywacjach państw dominowała wola kompromisu i negocjacji, nie zaś chęć realistycznego poszerzania wpływów. Większą wagę zwracało się też na wymianę gospodarczą między państwami ${ }^{23}$.

Model polityki zagranicznej Polski wobec zachodniego sąsiada kreowany przez polityków Platformy Obywatelskiej oparty był na dwóch filarach: (1) dorobku ostatnich lat w odbudowaniu przyjaznych stosunków polsko-niemieckich oraz (2) uznaniu dominującej roli Niemiec w UE. W przeciwieństwie do PiS często podkreślano wagę relacji polskoniemieckich i elementy wspólne w polityce Niemiec i Polski. Na określenie dobrosąsiedzkich relacji używano określeń: „wspólnota interesów”, „partnerstwo”, „wspólna, strategiczna wizja przyszłości Unii”, ,,wspólnota przeszłości”.

W przekonaniu polityków PO trwałym filarem pozytywnych tendencji w relacjach dwustronnych był dorobek obu stron w kształtowaniu partnerskich stosunków polsko-niemieckich począwszy od 1989 roku. Politycy PO wskazywali na dwa jego wymiary: symboliczny oraz realny. Wymiar symboliczny dotyczył sfery pamięci i pojednania między narodami, realny - polskiego członkostwa w NATO i UE, co było możliwe w dużym stopniu dzięki poparciu ze strony Niemiec, współpracy gospodarczej, kontaktów naukowo-badawczych, turystycznych i kulturalnych oraz kooperację transgraniczną i regionalną ${ }^{24}$.

W myśli politycznej Platformy Obywatelskiej Niemcy pełniły ważną rolę na trzech płaszczyznach: (1) bilateralnej, (2) regionalnej, (3) europejskiej. Po pierwsze - Niemcy były traktowane jako najważniejszy partner Polski w relacjach dwustronnych. Biorąc pod uwagę względy gospodarcze i finansowe zachodni sąsiad Polski był odbiorcą ponad jednej czwartej polskiego eksportu (wymiana handlowa była większa niż Niemiec z Rosją) i głównym płatnikiem netto do budżetu UE, z czego Polska czerpała wymierne korzyści finansowe. Uwzględniając czynniki polityczne Polskę i Niemcy łączyła wspólnota interesów i demokratycznych wartości, podobne postrzeganie sąsiedztwa Unii oraz szczególnie interesy unijne na Ukrainie i Białorusi.

Po drugie - doceniano regionalną współpracę trilateralną z Niemcami i Francją w ramach Trójkąta Weimarskiego. Oś Paryż-Berlin-Warszawa była geopolitycznym novum, które wyłoniło się w wyniku zakończenia ,zimnej wojny” i upadku Związku Radzieckiego. Początkowo zadaniem Trójkąta Weimarskiego było wprowadzenie Polski do zachodnich struktur politycznych i gospodarczych. W latach 2007-2015 obserwowaliśmy przeformułowanie idei Weimaru i jego reanimację po okresie stagnacji ${ }^{25}$. Poddawano krytyce politykę zagraniczną PiS, zarzucając Annie Fotydze, minister spraw zagranicznych nieumiejętność

\footnotetext{
${ }^{23}$ Zob. S.P. Sałajczyk, Wizje rzeczywistości międzynarodowej [w:] Stosunki międzynarodowe. Geneza, struktura, dynamika, red. E. Haliżak, R. Kuźniar, Warszawa 2006, s. 41 i n.; E. Haliżak, Liberalna wizja porzqdku międzynarodowego [w:] Porzadek międzynarodowy..., s. 59 i n.; J. Czaputowicz, op. cit., s. 104 i n.

24 Priorytety polskiej polityki zagranicznej 2012-2016, Warszawa 2012, s. 17.

${ }^{25}$ Ministrowie obrony Polski, Francji i Niemiec o wspótpracy, http://www.defence24.pl (dostęp: 20.06.2015 r.).
} 
tworzenia sojuszy politycznych oraz wykorzystania stosunków z Francją i Niemcami w ramach Trójkąta Weimarskiego do realizacji polskich interesów narodowych ${ }^{26}$.

Bronisław Komorowski, pełniąc funkcję marszałka Sejmu RP ocenił Trójkąt Weimarski jako „najbardziej atrakcyjną platformę współpracy Polski, Niemiec i Francji w Unii Europejskiej”, gwarantującą Polsce silną pozycję w regionie i platformę reprezentowania swoich interesów ${ }^{27}$. Politycy PO w kooperacji ramach Trójkąta Weimarskiego upatrywali nie tylko współpracy politycznej w obrębie UE, ale także militarnej.

Po trzecie - na płaszczyźnie europejskiej akcentowano pozytywną rolę „europeizacji” stosunków polsko-niemieckich oraz dominującą rolę Niemiec w UE. W tej kwestii uwypuklano zasługi Niemiec dla polskiego członkostwa w strukturach unijnych oraz podkreślano, że polityka wspólnotowa UE w znaczny sposób ograniczała asymetrię dwustronnych stosunków polsko-niemieckich, a różnice potencjałów obu państw nie tworzyły jednostronnej zależności, ale współzależność interesów w ramach UE. Wierzono, że bliska współpraca z Niemcami ,toruje nam drogę ku centrum decyzyjnemu Unii” i pomaga w oddziaływaniu na Rosję $e^{28}$

Niemcy widziano w roli gwaranta stabilności całej Unii Europejskiej, a bezpieczne członkostwo Polski w UE traktowano jako element racji stanu ${ }^{29}$. Minister spraw zagranicznych Radosław Sikorski w przemówieniu w Berlinie w 2011 roku wyraźnie określił stanowisko rządu: „Mniej zaczynam się obawiać się niemieckiej potęgi niż niemieckiej bezczynności. Niemcy stały się niezbędnym narodem Europy. Nie możecie sobie pozwolić na porażkę przywództwa. Nie możecie dominować, lecz macie przewodzić reformom"30.

Politycy PO odrzucali tym samym proponowaną przez PiS koncepcję bloku państw, będących przeciwwagą dla Rosji (poza UE) i Niemiec (w UE). Donald Tusk podkreślił, iż wizja międzymorza była „fikcyjnym aliansem państw, które nawet prowadząc wspólną politykę nie były w przeszłości i nie będą w przyszłości w stanie sprostać wyzwaniom, jakie stawia przed nami świat współczesny"31.

${ }^{26}$ Wypowiedź Bronisława Komorowskiego po informacji rządu na temat bilansu kosztów i korzyści związanych z członkostwem Polski w Unii Europejskiej od 1 maja 2004 r. do 1 maja 2006 r., http://orka2.sejm.gov.pl/Debata5.nsf/main/7D5C128B (dostęp: 3.07.2015 r.).

${ }^{27}$ Informacja ministra spraw zagranicznych o założeniach polskiej polityki zagranicznej w 2013 roku, http://www.sejm.gov.pl/sejm7.nsf/wypowiedz.xsp?posiedzenie=36\&dzien=1 \&wyp=0\#093 (dostęp: 10.07.2015 r.).

28 Informacja ministra spraw zagranicznych nt. polityki zagranicznej RP w 2011 roku, http://www.msz.gov.pl/resource/6fd9a0c0-79ef-4eac-82ef-5fbc4202948e:JCR (dostęp: 10.07. 2015 r.); Komorowski: mocna rola Polski w UE bez członkostwa w unii walutowej - watpliwa, http://www.radiopik.pl/3,33045,komorowski-mocna-rola-polski-w-ue-bez-czlonkostw\&s= $2 \& s i=2 \& s p=2$ (dostęp: 10.07.2015 r.).

${ }^{29}$ Informacja ministra spraw zagranicznych o założeniach polskiej polityki zagranicznej w 2011 roku, https://www.msz.gov.pl/pl/ministerstwo/historia/ministrowie_sz_1918_2014/wystapienia_ radoslawa_sikorskiego/ (dostęp: 2. 07. $2015 \mathrm{r}$.).

30 Wystąpienie ministra spraw zagranicznych RP Radosława Sikorskiego na forum Niemieckiego Towarzystwa Polityki Zagranicznej w Berlinie 28 listopada 2011 roku, http://www.msz.gov.pl/pl/ c//ministerstwo/historia/ministrowie_sz_1918_2014/wystapienia_radoslawa_sikorskiego/ (dostęp: 23.07.2015 r.).

31 Wypowiedź Donalda Tuska na Konwencji PO w Sopocie przed wyborami do europarlamentu w dniu 12.06.2014 r., http://www.platforma.org/aktualnosc/36601/przemowienie-donalda-tuskana-konwencji-w-sopocie-tekst (dostęp: 12.06.2015 r.). 
Dla myśli politycznej Platformy Obywatelskiej charakterystyczne było przekonanie, że Niemcy pełniły dominującą rolę w zjednoczonej Europie. Wielokrotnie akcentowano, że kryzys strefy euro po 2010 r. wyniósł Niemcy do roli rzeczywistego przywódcy UE, czyniąc z polskiego zachodniego sąsiada państwo dźwigające główny ciężar finansowy walki z kryzysem. „Kraj ten ugruntował swoją kluczową pozycję na kontynencie. W naszym interesie jest, aby Niemcy oddziaływały na Europę w ramach mechanizmu konsultacji, na które państwa członkowskie, a więc także my, mają spory wpływ”, podkreślił Radosław Sikorski ${ }^{32}$.

Wizja roli Niemiec w Unii Europejskiej wiązała się z poglądami na model integracji. PO wspierała projekt federalizacji UE, widząc w niej gwarancję bezpieczeństwa Polski, szczególnie we współpracy z Niemcami. Racją stanu pojmowano w sensie wspólnotowym (ponowoczesnym). Wedle polityków PO tylko silna i scentralizowana UE gwarantowałaby realizację polskiej racji stanu, natomiast Europa ojczyzn, będąca luźnym związkiem państw narodowych, realizujących własne interesy byłaby zagrożeniem dla bezpieczeństwa Polski i całego kontynentu ${ }^{33}$.

Politycy PO łagodnie traktowali sprawę Gazociągu Północnego. Radosław Sikorski wyraził zadowolenie, że strona niemiecka uwzględniła polskie postulaty, aby rurociąg „,nie zagrażał ani teraz, ani w przyszłości dostępowi do portu w Świnoujściu”. Uznał, że jest to przykład na realizację polskich interesów dzięki dobrym stosunkom polsko-niemieckim Jednocześnie podkreślił, że Polska nie jest entuzjastą tego projektu ${ }^{34}$. Za brak sprzeciwu wobec projektu North Stream został mocno skrytykowany przez polityków PiS.

$\mathrm{Na}$ kształt relacji polsko-niemieckich miały wpływ liczne kontrowersje historyczne ${ }^{35}$. Na początku XXI wieku spory zaostrzyły się i dotyczyły m.in. spraw związanych z: roszczeniami majątkowymi Niemców wysiedlonych z byłych obszarów Trzeciej Rzeszy (działalność Powiernictwa Pruskiego), budową Centrum przeciwko Wypędzeniom w Berlinie i polskim sprzeciwem wobec prób relatywizacji zbrodni niemieckich z czasów II wojny światowej.

W PO zdawano sobie sprawę z wagi kwestii historycznych dla pojednania narodów polskiego i niemieckiego, jednakże podkreślano, iż nie można pozwolić, aby spory o przeszłość spowodowały zaprzepaszczenie dorobku współpracy Polaków i Niemców z ostatnich dekad ${ }^{36}$. PO kładła nacisk na historię budowania dobrych relacji z Niemcami po 1989

${ }^{32}$ Informacja ministra spraw zagranicznych o założeniach polskiej polityki zagranicznej w 2011 roku, https://www.msz.gov.pl/pl/ministerstwo/historia/ministrowie_sz_1918_2014/wystapienia_ radoslawa_sikorskiego/ (dostęp: 2.07.2015 r.); Wypowiedź Donalda Tuska po sprawozdaniu Komisji Spraw Zagranicznych o poselskim projekcie uchwały w sprawie reparacji Niemiec na rzecz Polski, http://www.sejm.gov.pl/archiwum/2004r/pos83z.htm (dostęp: 24.06.2015 r.).

33 Wypowiedź Donalda Tuska na Konwencji PO w Sopocie przed wyborami do europarlamentu 12. 06. 2014 r., http://www.platforma.org/aktualnosc/36601/przemowienie-donalda-tuska-na-konwencji-w-sopocie-tekst (dostęp: 12.06.2015 r.).

${ }^{34}$ Nord Stream nie utrudni rozwoju portów, http://www.tvp.info/1419359/informacje/biznes/nordstream-nie-utrudni-rozwoju-portow/ (dostęp: 12.07.2015 r.).

35 Więcej w: B. Korzeniewski, Wprowadzenie. Polityka historyczna - propozycje definicji i spory wokót jej zakresu w polskim i niemieckim dyskursie naukowym [w:] Narodowe i europejskie aspekty polityki historycznej, red. B. Korzeniewski, Poznań 2008.

36 Wypowiedź Grzegorza Schetyny po sprawozdaniu Komisji Spraw Zagranicznych o poselskim projekcie uchwały w sprawie ustanowienia Centrum Pamięci Narodów Europy pod auspicjami Rady Europy, http://orka2.sejm.gov.pl/Debata4.nsf/9a905bcb5531f478c125745f0037938e/ 8495e9411f11fa89c125747800370e1e?OpenDocument (dostęp: 24.06.2015 r.). 
roku, których genezę upatrywała w liście biskupów polskich do biskupów niemieckich, uwypuklała znaczenie obalenia komunizmu w Europie dla Polski i dla Niemiec, starając się ,przełamywać negatywne skojarzenia związane z dramatem przeszłości, dramatem drugiej wojny światowej" ${ }^{37}$. Odcinano się od modelu polityki historycznej propagowanego przez swoich politycznych adwersarzy, podkreślając, że historia nie może „przesłaniać horyzontów przyszłości w relacjach między ludźmi, między narodami i między państwami”38.

Mimo „konfliktu odmiennej pamięci” Bronisław Komorowski, jako marszałek Sejmu RP, podkreślił polsko-niemiecką „wspólnotę złego losu”, opierającą się na tym, iż „dramat wojny dotknął prawie każdą polską rodzinę, [...] także prawie każdą niemiecką rodzinę. Doświadczenie totalitarnych dyktatur, zwycięska walka o wolność i przezwyciężenie trudnej przeszłości tworzą polską, niemiecką i europejską wspólnotę pamięci dobrego losu"39. Komorowski krytykował PiS za brak woli politycznej „,rozwiązywania problemów przyszłości” i „odwoływania się do negatywnych skojarzeń, lęków, obciążeń z natury historii pomiędzy relacjami polsko-niemieckimi”40.

Zmiana retoryki i „ocieplenie klimatu” relacji polsko-niemieckich nastąpiło w 2007 roku po przejęciu władzy politycznej przez rząd koalicyjny Platformy Obywatelskiej i Polskiego Stronnictwa Ludowego. Jednak nie przesądzało o większej skuteczności prowadzonej polityki, gdyż w dalszym ciągu wiele kwestii niezwykle istotnych z punktu widzenia polskiej racji stanu pozostało nierozwiązanych (nieokreślone warunki przyznania statusu mniejszości narodowej Polakom w Niemczech oraz finansowanie organizacji polonijnych, toczące się negocjacje w sprawie dostępu do portów w Szczecinie i Świnoujściu statków o dużym zanurzeniu przy okazji budowy Gazociągu Północnego $)^{41}$.

\section{WNIOSKI KOŃCOWE}

Analiza świadectw i śladów myśli politycznej Platformy Obywatelskiej oraz Prawa i Sprawiedliwości w kwestii stosunków polsko-niemieckich skłania do kilku wniosków. Po pierwsze - o ile istniał konsensus między partiami, że dobre relacje polsko-niemieckie były kluczowe dla polskiej racji stanu, o tyle kwestiami spornymi pozostawały drogi realizacji

${ }^{37}$ Bronistaw Komorowski w Bonn: Stawiam na Trójkąt Weimarski, http://www.dw.com/pl/bronis\%C5\%82aw-komorowski-w-bonn-stawiam-na-tr\%C3\%B3jk\%C4\%85t-weimarski/a-4934012 (dostęp: 23.06.2015 r.).

${ }^{38}$ Wypowiedź Bronisława Komorowskiego po informacji rządu na temat realizacji traktatu PolskoNiemieckiego o dobrym sąsiedztwie i przyjaznej współpracy z 17 czerwca 1991 roku, http:// orka2.sejm.gov.pl/Debata5.nsf/main/67E5240B (dostęp: 3.07.2015 r.).

${ }^{39}$ Bronistaw Komorowski: Trójkąt Weimarski sita w UE, http://www.dw.com/pl/bronis\%C5\%82awkomorowski-tr\%C3\%B3jk\%C4\%85t-weimarski-si\%C5\%82\%C4\%85-w-ue/a-4933545 (dostęp: 23.06.2015 r.).

40 Wypowiedź Bronisława Komorowskiego w debacie sejmowej po informacji Rządu na temat realizacji traktatu Polsko-Niemieckiego o dobrym sąsiedztwie i przyjaznej współpracy z 17 czerwca 1991 roku, http://orka2.sejm.gov.pl/Debata5.nsf/9a905bcb5531f478c125745f0037938e/ 7a3acddc077bca7bc12574650047567d?OpenDocument (dostęp: 23.06.2015 r.); Wypowiedź Bronisława Komorowskiego w debacie sejmowej po informacji informacji Ministra Spraw Zagranicznych o zadaniach polskiej polityki zagranicznej w 2007 r., http://orka2.sejm.gov.pl/Debata5.nsf/9a905bcb5531f478c125745f0037938e/07efb6580ddd0d66c1257466003fd87a?OpenDocument (dostęp: 23.06.2015 r.).

${ }^{41}$ M. Hajduk, Polityka zagraniczna wobec Niemiec [w:] Główne kierunki polityki zagranicznej..., s. 203. 
założonych celów. Po drugie - obie partie zasadniczo różniły się w propagowanym modelu polityki zagranicznej. Stanowisko PO bliskie było liberalnemu podejściu do relacji międzynarodowych oraz ponowoczesnemu modelowi państwa ${ }^{42}$. Zwolennicy państwa ponowoczesnego nie przywiązywali wagi do suwerenności jako szczególnego atrybutu państwa, a interes państwowy traktowali jako coraz mniej determinujący czynnik w polityce zagranicznej. PiS natomiast hołdowało paradygmatowi realistycznemu, uważając, że stosunki międzynarodowe były nieustanną areną walki między partykularnymi interesami poszczególnych państw, gdzie rządzą narodowe egoizmy. Uznawano, że tylko podejście realistyczne gwarantuje dobre relacje bilateralne z Niemcami. Kierowanie się w polityce zagranicznej czynnikami irracjonalnymi (kwestie etyczne, moralne, pojednanie, dialog, solidarność etc.) uważano za wysoce nieskuteczne. Politycy PiS byli zwolennikami modelu państwa narodowego. Uznawano suwerenność państwową za kluczową cechę państwa, a siła, podmiotowość i racja stanu determinowały relacje między państwami. W myśli politycznej PiS państwa w stosunkach międzynarodowych kierowały się przede wszystkim rachunkiem interesów i sił. Po trzecie - Platforma Obywatelska określała RFN mianem ,partnera strategicznego”, z którym łączyła Polskę „,wspólnota losów i interesów”. Politycy PiS unikali określenia „partnerstwo”, uważając relacje polsko-niemieckie za ,asymetryczne”. W zamian proponowano jasne artykułowanie racji stanu i nieunikanie kwestii spornych w debacie międzynarodowej. Po czwarte - w myśli politycznej PO dominowało przekonanie, że kierowanie się racją stanu sprzyjało konfliktom i egoizmom państwowym, podobnie jak częste sięganie do kwestii historycznych. PO kładła nacisk na historię budowania dobrych relacji z Niemcami po 1989 roku. Odpowiedzią PiS była konstatacja, że tylko jasne artykułowanie swoich interesów może gwarantować dobre relacje z innymi państwami. Po piąte - PiS i PO znacząco różniły się w postrzeganiu roli Niemiec w zjednoczonej Europie. PO niejako ,pod skrzydłami Niemiec” chciała realizować polskie interesy i cele polskiej polityki, co dla PiS było zgodą na klientelizm i odebranie podmiotowości Polski na arenie międzynarodowej. Zwiększenie roli Niemiec było dla PiS niczym innym niż utrwaleniem modelu „dwóch prędkości” w UE.

\section{LITERATURA}

[1] Bieleń S., Polityka zagraniczna a racja stanu [w:] Polityka zagraniczna państwa, red. J. Kukułka, R. Zięba, Warszawa 1992.

[2] Cerny P.G., The competition state today: from raison d'État to raison du Monde, "Policy Studies" Vol. 31, 2010.

[3] Graś A., Pozycja prawna Polaków w Niemczech [w:] Być Polakiem w Niemczech, red. A. Wolff-Powęska, E. Schulz, Poznań 2000.

[4] Groszyk H., Refleksje o niektórych aspektach idei racji stanu [w:] Studia z historii państwa i idei, red. A. Korobowicz, H. Olszewski, Lublin 1997.

[5] Hajduk M., Polityka zagraniczna wobec Niemiec [w:] Główne kierunki polityki zagranicznej rządu Donalda Tuska w latach 2007-2011, red. P. Musiałek, Kraków 2012.

[6] Kiperska J., USA w polityce Niemiec, ,Przegląd Zachodni” nr 1, 2008. ${ }^{42}$ Zob. K. Szpak, Zatożenia programowe polityki zagranicznej koalicji rządowej PO-PSL w latach
2007-2011 [w:] Gtówne kierunki polityki zagranicznej...., s. 19. 
[7] Korzeniewski B., Wprowadzenie. Polityka historyczna - propozycje definicji i spory wokót jej zakresu w polskim i niemieckim dyskursie naukowym [w:] Narodowe i europejskie aspekty polityki historycznej, red. B. Korzeniewski, Poznań 2008.

[8] Łastawski K., Polska racja stanu po wstapieniu do UE, Warszawa 2006.

[9] Michałowski S., Partnerstwo Wschodnie w polityce zagranicznej Niemiec, „Homo Politicus" Vol. 7-8, 2012-2013.

[10] Musiałek P., Trendy zewnętrznych uwarunkowań polityki zagranicznej Polski w latach 2007-2011. Ewolucja najbliższego środowiska międzynarodowego [w:] Gtówne kierunki polityki zagranicznej rządu Donalda Tuska w latach 2007-2011, red. P. Musiałek, Kraków 2012.

[11] Paruch W., Rydel M., Założenia strategiczne w koncepcji polityki zagranicznej RP - analiza myśli politycznej Prawa i Sprawiedliwości [w:] Polityka zagraniczna III RP. 20 lat po przełomie, t. 1: Koncepcje, bezpieczeństwo, kwestie prawne i polonijne, red. A. Jarosz, K. Olszewski, Torun 2011.

[12] Pietraś Z.J., Racja stanu w polityce zagranicznej państwa [w:] Racja stanu. Historia. Teoria. Współczesność, red. E. Olszewski, Lublin 1989.

[13] Rzegocki A., Idea raison d'état w przeszłości i w kontekście wspótczesnej integracji europejskiej, Warszawa 2003.

[14] Sadowski E., Racja stanu w polityce zagranicznej państwa [w:] Wstęp do teorii polityki zagranicznej państwa, red. R. Zięba, Toruń 2004.

[15] Sałajczyk S.P., Wizje rzeczywistości międzynarodowej [w:] Stosunki międzynarodowe. Geneza, struktura, dynamika, red. E. Haliżak, R. Kuźniar, Warszawa 2006.

[16] Santorski J., Problem Polonii niemieckiej w zjednoczonych Niemczech - aspekty historyczne, polityczne i prawnomiędzynarodowe [w:] Przełom i wyzwanie. XX lat polsko-niemieckiego Traktatu o dobrym sąsiedztwie i przyjaznej wspótpracy 1991-2011, red. W.M. Góralski, Warszawa 2011.

[17] Stolarczyk M., Zbieżność i różnice interesów $w$ stosunkach polsko-niemieckich $w$ latach 1989-2009, Katowice 2010.

[18] Szpak K., Założenia programowe polityki zagranicznej koalicji rzadowej PO-PSL w latach 2007-2011 [w:] Gtówne kierunki polityki zagranicznej rzqdu Donalda Tuska w latach 2007-2011, red. P. Musiałek, Kraków 2012.

[19] Warzecha Ł., Czy możliwa jest realistyczna polityka zagraniczna nie na kolanach, czyli o fatszywej interpretacji realizmu [w:] Rzeczpospolita na arenie międzynarodowej. Idee i praktyczne dylematy polityki zagranicznej, red. J. Kloczkowski, T. Żukowski, WarszawaKraków 2010.

[20] Wolff-Powęska A., Polska racja stanu w procesie normalizacji stosunków z Niemcami $w$ warunkach wolności i demokracji [w:] Polska-Niemcy 1945-2007. Od konfrontacji do wspótpracy i partnerstwa w Europie, red. W.M. Góralski, Warszawa 2007.

\section{ŹRÓDŁA}

A) Dokumenty programowe:

[1] Priorytety polskiej polityki zagranicznej 2012-2016, Warszawa 2012.

[2] Program Prawa i Sprawiedliwości 2014, Warszawa 2014.

[3] Raport o stanie Rzeczypospolitej, Warszawa 2011. 
B) Prasa:

[1] Fotyga A., Sojusze zawieramy wedle interesów, rozm. J. Olechowski, W. Lorenz, „Rzeczpospolita” z 18.05.2007 r.

[2] Kaczyński J., Nie odtwarzajmy Cesarstwa Niemieckiego, „Rzeczpospolita” z 8.12. $2011 \mathrm{r}$.

[3] Kaczyński J., Polska racja stanu [w:] Racja stanu - Janowi Olszewskiemu, red. B. Jusiak, Poznań 2011.

[4] Naimski P., Rosja chce być energetycznym monopolista, rozm. I. Janke, ,Rzeczpospolita" z 11.01.2008 r.

[5] Szczerski K., Będziemy prowadzić politykę z podniesiona głowa, rozm. M. Michalska, „Gazeta Polska” z 24.08.2014 r.

[6] Szczerski K., Cztery warunki Dudy dla Niemiec, rozm. J. Bielecki, „Rzeczpospolita” $\mathrm{z} 15.06 .2015 \mathrm{r}$.

\section{NETOGRAFIA}

[1] Bronisław Komorowski w Bonn: Stawiam na Trójkąt Weimarski, http://www.dw.com/ $\mathrm{pl} /$ bronis\%C5\%82aw-komorowski-w-bonn-stawiam-na-tr\%C3\%B3jk\%C4\%85t-weimarski/a-4934012

[2] Bronisław Komorowski: Trójkąt Weimarski siłą w UE, http://www.dw.com/pl/bronis\% C5\%82aw-komorowski-tr\%C3\%B3jk\%C4\%85t-weimarski-si\%C5\%82\%C4\%85-w-ue/a4933545

[3] Dylematy i perspektywy stosunków polsko-niemieckich, http://www.stosunkimiedzynarodowe.info/artykul,587,Dylematyiperspektywy_stosunkow_polskoniemieckich

[4] Informacja ministra spraw zagranicznych o założeniach polskiej polityki zagranicznej w 2011 roku, https://www.msz.gov.pl/pl/ministerstwo/historia/ministrowie_sz_1918_ 2014/wystapienia_radoslawa_sikorskiego/

[5] Informacja ministra spraw zagranicznych o założeniach polskiej polityki zagranicznej w $2013 \mathrm{roku}$, http://www.sejm.gov.pl/sejm7.nsf/wypowiedz.xsp?posiedzenie=36\&dzien= $1 \&$ wyp $=0 \# 093$

[6] Informacja ministra spraw zagranicznych o założeniach polskiej polityki zagranicznej w 2011 roku, https://www.msz.gov.pl/pl/ministerstwo/historia/ministrowie_sz_1918_ 2014/wystapienia_radoslawa_sikorskiego/

[7] Komorowski: mocna rola Polski w UE bez czlonkostwa w unii walutowej - watpliwa, http://www.radiopik.pl/3,33045,komorowski-mocna-rola-polski-w-ue-bezczlonkostw\&s $=2 \& \mathrm{si}=2 \& \mathrm{sp}=2$

[8] Ministrowie obrony Polski, Francji i Niemiec o wspótpracy, http://www.defence24.pl

[9] Nord Stream nie utrudni rozwoju portów, http://www.tvp.info/1419359/informacje/ biznes/nord-stream-nie-utrudni-rozwoju-portow/

[10] Od lat jesteśmy w sporze o bezpieczeństwo Europy Wschodniej z Niemcami, http://wiadomosci.onet.pl/kraj/waszczykowski-od-lat-jestesmy-w-sporze-o-bezpieczenstwo-europywschodniej-z-niemcami/9s2jhy

[11] Trójkąt Weimarski: propaganda zamiast narzędzia, http://ryszardczarnecki.blog.onet.pl/ tag/francja/. 
[12] Waszczykowski: Chcemy dokonać korekty w relacjach z Niemcami, http://natemat.pl/ 145845,chcemy-dokonac-korekty-w-relacjach-z-niemcami-waszczykowski.

[13] Wypowiedź Arkadiusza Mularczyka po informacji ministra spraw zagranicznych o zadaniach polskiej polityki zagranicznej w 2015 r., http://www.sejm.gov.pl/Sejm7.nsf/wypowiedz.xsp?posiedzenie $=91 \&$ dzien $=2 \& w y p=42 \&$ view $=S$.

[14] Wypowiedź Bronisława Komorowskiego po informacji rządu na temat realizacji traktatu Polsko-Niemieckiego o dobrym sąsiedztwie i przyjaznej współpracy z 17 czerwca 1991 roku, http://orka2.sejm.gov.pl/Debata5.nsf/main/67E5240B

[15] Wypowiedź Donalda Tuska na Konwencji PO w Sopocie przed wyborami do europarlamentu 12 IV 2014 r.”, http://www.platforma.org/aktualnosc/36601/przemowienie-donalda-tuska-na-konwencji-w-sopocie-tekst

[16] Wypowiedź Donalda Tuska po sprawozdaniu Komisji Spraw Zagranicznych o poselskim projekcie uchwały w sprawie reparacji Niemiec na rzecz Polski, http://www.sejm. gov.pl/archiwum/2004r/pos83z.htm

[17] Wypowiedź Jarosława Kaczyńskiego po informacji rządu na temat polskiej polityki zagranicznej w 2003 roku, http://orka2.sejm.gov.p1/Debata4.nsf/ 9a905bcb5531f478c125745f0037938e/.

[18] Wypowiedź Kazimierza Michała Ujazdowskiego po informacji ministra spraw zagranicznych o zadaniach polskiej polityki zagranicznej w 2005 roku, http://orka2.sejm.gov.pl/Debata4.nsf/9a905bcb5531f478c125745f0037938e/.

[19] Wypowiedź Witolda Waszczykowskiego po informacji ministra spraw zagranicznych o założeniach polskiej polityki zagranicznej w 2013 r., http://www.sejm.gov.pl/Sejm7.nsf/ wypowiedz.xsp?posiedzenie=36\&dzien=1\&wyp=4\&type=A\&symbol.

[20] Wystąpienie ministra spraw zagranicznych RP Radosława Sikorskiego na forum Niemieckiego Towarzystwa Polityki Zagranicznej w Berlinie 28 listopada 2011 roku, http://www.msz.gov.pl/pl/c//ministerstwo/historia/ministrowie_sz_1918_2014/wystapienia_radoslawa_sikorskiego/

\section{POLISH-GERMAN RELATIONS AND THE NATIONAL INTEREST. THE PIS-PO DISPUTE ABOUT THE MODEL OF FOREIGN POLICY TOWARDS THE FEDERAL REPUBLIC OF GERMANY (2001-2015)}

The analysis of the testimonies and political thought of Civic Platform (PO) and Law and Justice (PiS) leads to three conclusions. Firstly, while there was a consensus between these two parties that good Polish-German relations were crucial to the Polish national interest, the ways of achieving the target objectives remained the sticking point. Secondly, PiS and PO displayed fundamental differences in the propagated models of foreign policy. PO's standpoint was close to a liberal attitude to international relations and the postmodern model of the state (the state's sovereignty is not regarded as its main asset, with the national interest determining state foreign policy to a lesser and lesser extent). PiS followed a realistic paradigm, believing that international relations are an arena of constant struggle between particular interests of individual states, governed by national egoism. It was deemed that only a realistic approach can guarantee good bilateral relations with Germany. PiS politicians advocated a modern state model (with state sovereignty regarded as extremely important). Thirdly, PO treated Germany as a "strategic partner", while PiS avoided the 
word "partnership", considering it a pipe dream and an empty slogan. Instead, it proposed the clear articulation of the national interest and not avoiding points of dispute in the international debate.

Keywords: Reason of State, Political Thought, Political Parties, Polish-German Relations.

DOI: $10.7862 /$ rz.2017.hss.73

Przestano do redakcji: grudzień 2017 r.

Przyjęto do druku: grudzień 2017 r. 